\title{
Therapeutic implications of the endocannabinoid system in neurodegenerative diseases
}

\author{
Panagiotis Zogopoulos, Georgios Vretakos and Dimitrios Rologis \\ Department of Neurosurgery, Metropolitan Hospital, Athens, Greece
}

\begin{abstract}
Over the last years, considerable progress has been made in understanding the role of the endocannabinoid system in the modulation of several progressive neurodegenerative diseases. The endocannabinoid system, comprised of cannabinoid receptors (type-1 and type-2), their endogenous ligands [referred to as endocannabinoids, of which anandamide (AEA) and 2-arachidonoylglycerol (2-AG) are most studied] and proteins responsible for their metabolism, is involved in several physiological processes. Endocannabinoids modulate neuronal, glial and endothelial cell function and exert neuromodulatory, anti-excitotoxic, antiinflammatory and vasodilatory effects. They have been found to exert neuroprotection in several conditions, such as cerebral ischemia, brain injury, neuroinflammation and excitotoxicity linked to seizure activity and associated neurodegeneration.
\end{abstract}

The endocannabinoid system and its pharmacological modulation is a promising field for the therapeutic intervention at a wide spectrum of diseases such as Parkinson's disease, Alzheimer's disease, Huntington's chorea, multiple sclerosis, amyotrophic lateral sclerosis and epilepsy. The purpose of this review is to present the available research and clinical data, up to date, regarding therapeutic perspectives of the endocannabinoid system in such neurodegenerative diseases.

\section{Introduction}

The endocannabinoid system (ECS) is involved in a variety of physiological processes including nociception, appetite, lipid metabolism, gastrointestinal motility, cardiovascular modulation, pain-sensation, motor activity, mood and memory [1-11].

Recently, a large number of researches have focused on the possible implications of the ECS on pain modulation, neuroprotection and antitumor actions [12-14]. Cannabinoids and endocannabinoids are promising candidates for the therapeutic armamentarium towards various neurodegenerative diseases such as Parkinson's disease, Alzheimer's disease, Huntington's chorea, amyotrophic lateral sclerosis and multiple sclerosis (Figure 1).

\section{The endocannabinoid system}

The ECS is comprised of two known G-protein coupled receptors, cannabinoid receptor type-1 (CB1R) and type-2 (CB2R), their endogenous lipid-based ligands (the endocannabinoids-eCBS) of which anandamide ( $\mathrm{N}$-arachidonoylethanolamine, AEA) and 2-arachidonoylglycerol (2-AG) are best defined [15-19] and the proteins that are responsible for their biosynthesis, transport and degradation [20].

Cannabinoid receptors are seven-transmembrane, G-proteincoupled receptors, which are negatively coupled to adenylyl cyclase [21-24].

CB1 receptors are one of the most abundant G-protein-coupled receptors in the mammalian brain, but they are also expressed in peripheral tissues (including myocardium, human coronary artery endothelial and smooth muscle cells, adipose tissue and various cell types of the liver) [25-29]. CB1R are highly expressed in regions of the brain, such as the cortex, limbic system, hippocampus, cerebellum, brainstem and several nuclei in the basal ganglia (associated with emotion, cognition, memory, motor and executive function) [5]. More specifically, they are expressed in brain areas involved in nociceptive transmission and processing including the periaqueductal gray (PAG), anterior cingulate cortex (ACC) and thalamus in addition to the dorsal horn of the spinal cord and dorsal root ganglion [30-34]. CB1R are found primarily at the terminals (but also at the axons, cell bodies and dendrites) of central and peripheral neurons, where they typically mediate the inhibition of amino acid and monoamine neurotransmitter release, as occurs with the inhibitory neurotransmitter gammaaminobutyric acid (GABA) [35-39].

CB2 receptors in the brain, are expressed primarily in perivascular microglial cells [40,41] and astrocytes [42,43], where they modulate immune responses [44-46]. They are also expressed in cerebromicrovascular endothelial cells [47] and in central (brainstem) and peripheral neurons [48-50]. Furthermore, CB2R are found on the cells of the immune system throughout the whole body, including thymus, spleen, tonsils, lymph nodes and blood mononuclear cells. B lymphocytes, macrophages, monocytes, natural killer (NK) cells and polymorphonuclear cells express CB2, with B lymphocytes and $\mathrm{T}$ lymphocytes expressing the most and least amounts of $\mathrm{CB} 2$, respectively $[51,52]$. CB2R are also expressed in the myocardium, human coronary endothelial and smooth muscle cells and the liver [27-29].

Correspondence to: Panagiotis Zogopoulos, Department of Neurosurgery, Metropolitan Hospital, 69 Vosporou str., Athens, Greece, Tel: +306976053555; E-mail: p.zogopoulos@yahoo.com

Key words: endocannabinoids, neurodegenerative disease, Parkinson's disease, Alzheimer's disease, Huntington's chorea, multiple sclerosis, amyotrophic lateral sclerosis, epilepsy

Received: April 03, 2015; Accepted: May 05, 2015; Published: May 08, 2015 
Endocannabinoids (eCBs) are endogenous metabolites of eicosanoid fatty acids. They are lipid signalling mediators of the same cannabinoid receptors that mediate the effects of $\Delta^{9}$ tetrahydrocannabinol ( $\Delta^{9}$-THC), the primary psychoactive ingredient of marijuana [5,7,53-55]. They are derivatives of arachidonic acid conjugated with either ethanolamine or glycerol. Apart from AEA (N-arachidonoylethanolamine) and 2-AG (2-arachidonoylglycerol), which have been most studied, endocannabinoids also include $\mathrm{N}$-arachidonoyldopamine (NADA), 2-arachidonoylglyceryl ether (2AGE, noladin ether) and O-arachidonoylethanolamine (virodhamine) [15,56-60].

\section{Neurodegenerative diseases}

Physiological stimuli and pathological conditions lead to differential increases in brain eCBs that regulate distinct biological functions. Physiological stimuli lead to rapid and transient (seconds to minutes) increases in eCBs that activate neuronal CB1 receptors, modulate ion channels and inhibit neurotransmission [61], whereas pathological conditions lead to much slower and sustained (hours to days) increases in $\mathrm{eCB}$ tone that change gene expression, implementing molecular mechanisms that prevent the production and diffusion of harmful mediators [25,62-67].

Endocannabinoids, primarily by binding to cannabinoid receptors, modulate neuronal, glial and endothelial cell function and exert neuromodulatory, anti-excitotoxic [25,68], anti-inflammatory [69-72] and vasodilatory effects (cannabinoids increase the diameter of cerebral arterioles and cerebral arteries in a CB1 receptor-dependent fashion, indicating that the main cerebrovascular effect of cannabinoids is vasodilation) $[64,73]$.

Endocannabinoidshavebeendemonstrated toexertneuroprotection against ischemia, traumatic brain injury and inflammation-induced neuronal damage and also against $\beta$-amyloid-, $\mathrm{N}$-methyl-d-aspartate (NMDA)-, and kainic acid-induced neurotoxicity [25,63,74-78].

\section{ECS and neuroinflammation}

Neuroinflammation is a biological immune response to various endogenous and exogenous stimuli in the nervous system and localized inflammatory responses in the brain parenchyma have been associated with the pathogenesis and progression of numerous neurological disorders and neurodegenerative diseases, including infection, ischemia, multiple sclerosis, Alzheimer's disease and Parkinson's disease [79-85]. At such lesion sites, activated microglia release several types of inflammatory mediators, such as toxic cytokines and oxygen radicals that contribute towards the impairment of the bloodbrain barrier (BBB) function and subsequently result in secondary neuronal damage $[76,86]$. Among these mediators, prostaglandin E2 (PGE2) is of major importance for the initiation, propagation and modulation of brain inflammation. AEA increases PGE2 and PGD2 production in activated glial cells [87]. Although the primary causes of neurodegenerative diseases are varied, microglia activation and the subsequent release of pro-inflammatory cytokines, radical oxygen species and prostaglandins play a role of paramount importance in cerebral damage [87]. In experimental studies, submicromolar concentrations of AEA protected cells exposed to hypoxia and glucose deprivation [88]. In contrast, higher concentrations of AEA may induce neuronal toxicity in vitro and in vivo [89,90], possibly through enhancing PGE2 and free radical formation by activated astrocytes and microglial cells, thus leading to oxidative stress [91-93]. On the other hand, NADA (N-arachidonoyldopamine) inhibits both AEA-induced
PGE2 and 8-iso-PGF2a formation in glial cells [87]. Therefore, in some studies AEA and NADA presented opposite effects in glial cells [87].

$\mathrm{CB} 2$ receptor blockade has been found to inhibit splenocyte proliferation and induce apoptosis in vitro [94]. CB2R also regulate $\mathrm{B}$ and $\mathrm{T}$ cell differentiation, and the balance of $\mathrm{T}$ helper 1 (Th1) proinflammatory to Thelper 2 (Th2) anti-inflammatory cytokines [95]. In macrophages, $\mathrm{CB} 2$ stimulation suppresses proliferation and the release of pro-inflammatory factors such as NO, IL-12, and TNF-a, inhibits phagocytosis, and reduces IL-2 signalling to Tcells [96]. CB2 activation also suppresses neutrophil migration and differentiation, but induces natural killer cell migration [97].

2-AG, apart from traumatic brain injury, has also been shown to protect neurons from insults such as excitotoxicity and ischemia both in vitro and in vivo [63,98-100]. Microglial cells that become activated during pathologies like excitotoxicity and ischemia are targeted by 2-AG which modulates their migration and proliferation and also inhibits the production and release of proinflammatory cytokines (including TNF- $\alpha$ ) and the expression of COX-2 [70,71,101-103]. Few studies, however, imply that under certain conditions 2-AG may act as a proinflammatory substance [104-106]. Particularly, COX-2 oxidative metabolites of the endocannabinoids may induce neurotoxicity by enhancing excitatory glutamatergic synaptic transmission, thus contributing to the inflammation-induced neurodegeneration [107-109]. COX-2-mediated neuronal injury/degeneration is likely attributed to the increased production of AA (arachidonic acid)-derived prostaglandins, mainly prostaglandin E2 (PGE2) [110-115]. While PGE2 is believed to promote neuronal injury in neuroinflammation, it may also protect neurons from glutamate-induced excitotoxicity and inflammation- or ischemia-induced neurodegeneration [116-119]. These contradictory observations suggest that there may be another pathway involved in the COX-2-mediated neurodegenerative process. The PGE2-G-induced actions are not mediated via a cannabinoid receptor 1 (CB1R), but mediated via extracellular signal-regulated kinase (ERK), p38 mitogen-activated protein kinase (MAPK), inositol 1,4,5-trisphosphate (IP3), and nuclear factor- $\mathrm{BB}$ (NF- $\mathrm{KB}$ ) signal transduction pathways. 2-AG decreases, while PGE2-G increases the frequency of mEPSCs (miniature excitatory post-synaptic currents) [109]. PGE2-G induces neurotoxicity, through the phosphorylation of MAPK and NF- $\kappa$ B. Glutamate receptor antagonists block PGE2G-induced neurotoxicity. Inhibition of COX-2 prevents ischemia or NMDA-induced cell death [120,121]. Elevated neurotoxic PGGs and reduced neuroprotective 2-AG are an important mechanism contributing to the COX-2-mediated neurodegeneration during neuroinflammation [109].

2-AG also acts on microglial $\mathrm{CB} 2$ receptors and increases their proliferation [40]. Experiments with CB1 and CB2 receptor-deficient mice have revealed the existence of further, not yet cloned but pharmacologically and functionally well characterized CB receptors [122]. The abnormal-cannabidiol (abnCBD)-sensitive receptor is one of these pharmacologically identified non-CB1/non-CB2 receptors and has been first described on endothelial cells of rat mesenteric blood vessels [123]. This receptor is activated by the endocannabinoid AEA and the synthetic agonist abn-CBD ((2)-4-(3-3,4-trans-p-menthadien1,8)-yl-olivetol), a derivative of the phytocannabinoid CBD. Abn$\mathrm{CBD}$-sensitive receptor-mediated effects have also been described for microglial cells: the endocannabinoid 2-AG triggers the migration of microglial cells via activation of the abn-CBD-sensitive receptor [70,71,124]. Moreover, 2-AG attenuates the LPS (lipopolysaccharide)induced release of proinflammatory cytokines like TNF-alpha from 
microglial cells independently from CB1 and CB2 receptors [101,125].

\section{ECS and Parkinson's disease}

Parkinson's disease (PD) is a chronic, progressive neurodegenerative movement disorder. In $\mathrm{PD}$, dopamine production in the basal ganglia is altered. Dopamine is the neurotransmitter that stimulates motor neurons, the nerve cells that control movement. PD results from the degeneration of dopamine-producing neurons in the brain, specifically in the substantia nigra and the locus coeruleus. When dopamine production is depleted, the motor system nerves are unable to control movement and coordination. Characteristic primary symptoms of $\mathrm{PD}$ are tremor, rigidity, slow movement (bradykinesia) and difficulty walking. Oxidative damage of dopaminergic neurons has been postulated as a mechanism of neuronal degeneration.

Evidence suggests that cannabinoids may prove useful in Parkinson's disease by inhibiting the excitotoxic neurotransmitter glutamate and counteracting oxidative damage to dopaminergic neurons. The inhibitory effect of cannabinoids on reactive oxygen species, glutamate and tumor necrosis factor suggests that they may be potent neuroprotective agents $[126,127]$. The endocannabinoid system, therefore, might play some physiological role in the control of movement by the basal ganglia [128]. The globus pallidus and substantia nigra pars reticulata contain the highest density of $\mathrm{CB} 1$ receptors in the body. $\mathrm{CB} 1$ receptors are also abundant in the putamen, part of the relay system within the basal ganglia that regulates body movements, and in the cerebellum, which coordinates body movements. Cannabinoid receptors are also found in the neurons that project from the striatum and subthalamic nucleus, which inhibit and stimulate movement, respectively. They are, therefore, possible additional sites that might underlie the effects of cannabinoids on movement. This is supported by the finding that CB1 knockout mice exhibit lower locomotor activity [129]. Furthermore, the concentration of anandamide in the globus pallidus and substantia nigra is three times higher than in other brain regions. Cannabinoids decrease both the inhibitory and stimulatory inputs to the substantia nigra, and therefore might provide dual regulation of movement at this nucleus, producing an upregulation of $\mathrm{CB} 1$ receptors. The antidyskinetic function of cannabinoid agonists may be exerted through inhibition of GABA reuptake in the lateral part of the globus pallidus. On the other hand, treatment with CB1 receptor antagonists may also be used to control akinesia in PD [130]. In an early clinical report, however, no effects of smoked cannabis were observed in parkinsonian tremor [131]. Preclinical research in animal models of several movement disorders have shown variable evidence for symptomatic benefits, but more consistently suggest potential neuroprotective effects in several animal models of PD [128].

\section{ECS and Alzheimer's disease}

Alzheimer's disease is not a motor disorder in nature, but, in addition to classic symptoms that affect cognition and memory, this disease also exhibits a variety of motor disturbances presumably due to the degeneration of cortical afferences to the basal ganglia circuitry. Studies with postmortem brain regions of patients affected by this disease have revealed a significant loss of CB1 receptors which seems notably circumscribed to the basal ganglia, in particular to the caudate nucleus, medial globus pallidus and substantia nigra. Brain regions other than the basal ganglia were less affected or did not exhibit any changes for the CB1 receptor, except for the hippocampus which also showed significant reductions [132]. However, these results might be more related to increasing age rather than to an effect selectively associated with the pathology characteristic of Alzheimer's disease. Although still preliminary, recent reports suggest that modulation of the endocannabinoids system may constitute a novel approach for the treatment of Alzheimer's disease [133].

\section{ECS and Huntington's disease}

Huntington's disease (Huntington's chorea) is a fatal, neurodegenerative disorder characterized by a selective degeneration of striatal projection neurons, which deal with choreic movements. It is inherited via sex chromosomes (it is rare in women who may nevertheless carry the disease) and usually develops in middle-aged males. There is a gradual loss of mental and cognitive function, commonly associated with depression and progressive loss of voluntary motor control. It has been suggested that the neuronal degeneration caused by the disease results from an excess of free radical oxidation or glutamate. Excitotoxicity has been implicated in the etiology of Huntington's disease, because intrastriatal injection of glutamate receptor agonists reproduces some of the neuropathological features of this disorder [134]. Furthermore, a selective loss ( $\approx 97 \%)$ of cannabinoid receptors and neurotransmitters alterations in specific regions of the brain, like the corpus striatum, substantia nigra and globus pallidus of Huntington's patients has been demonstrated [135,136]. Therefore, endocannabinoids, through the inhibition of glutamate release and/ or the reduction of reactive oxygen species, could be a promising treatment of Huntington's disease, since potential neuroprotective effects have been found in various animal models of Huntington's disease $[128,137]$.

\section{ECS and multiple sclerosis}

Multiple Sclerosis (MS) has been recognized as a neurodegenerative disease that is triggered by inflammatory attack of the CNS. When MS has been active for some years it can cause muscle stiffness and spasms, pain, fatigue, difficulty passing urine and tremors. CB1 receptors are involved in the pathophysiology of MS. The cannabinoid system has been found to be neuroprotective in an animal model of MS, the allergic encephalomyelitis (EAE) model [138]. Cannabinoid receptor agonists were able to reduce spasticity and tremor in a mouse model of EAE (chronic relapsing experimental allergic encephalomyelitis) $[139,140]$. In addition, several studies suggest that cannabinoids and endocannabinoids may have a key role in the pathogenesis and therapy of MS $[133,141,142]$. In EAE and, at least initially, in MS, axonal damage and demyelination occur at least concurrently with inflammation $[143,144]$, which produces many potentially damaging elements such as cytokines and oxidative stress [145]. Indeed, eCBs can downregulate the production of $\mathrm{T}$ helper 1-associated pathogenic cytokines, enhancing the production of T helper 2-associated protective cytokines [146]. A shift towards T helper 2 has been associated with therapeutic benefit of cannabinoids in MS. Recently, a distinct immunomodulatory effect of AEA in dendritic cells from MS patients has been shown, which may pave the way for the design of new endocannabinoid-based immunotherapeutic agents targeting a specific cell subset [147].

\section{ECS and amyotrophic lateral sclerosis}

Amyotrophic lateral sclerosis (ALS) is a motor neuron disease caused by the degeneration of neurons located in the ventral horn of the spinal cord and the cortical neurons that provide their afferent input. The disorder is characterized by rapidly progressive weakness, muscle atrophy and fasciculations, spasticity, dysarthria, dysphagia and respiratory compromise. The cause of ALS is not yet known, but studies have shown that ALS patients have increased free radicals 
accumulation and increased levels of glutamate in the serum and spinal fluid. Therefore, decreasing the release of glutamate via activation of the endocannabinoid system, combined with its antioxidant properties, could be proven useful in the treatment of ALS $[141,148]$.

\section{ECS and epilepsy}

In experimental models of epilepsy, levels of anandamide (but not $2 \mathrm{AG})$ in the hippocampus of mice after kainic acid-induced seizures were found to be transiently increased $[25,149]$. These studies revealed that seizures rapidly activate the endogenous cannabinoid system, which provides protection against excessive neuronal activity by reducing excitability of hippocampal pyramidal neurons and activating intracellular signalling cascades [150]. Exogenous cannabinoids, as well as endocannabinoids can limit seizures and neurodegeneration [151]. Endocannabinoids are mobilized by epileptiform activity and in turn influence this activity by inhibiting synaptic transmission in both excitatory and some inhibitory synapses [151].

\section{Discussion}

Over the last years, considerable progress has been made in understanding the role of endocannabinoids in preventing or reducing the effects of progressive neurodegenerative diseases. The ECS has been shown to mediate neuroprotection in many neurological and psychiatric disorders including pain, schizophrenia, anxiety, depression, Parkinson's disease, Alzheimer's disease, Huntington's chorea, multiple sclerosis, amyotrophic lateral sclerosis and epilepsy [152-156]. It also has neurotrophic and neuroprotective effects in cerebral ischemia (stroke) and traumatic brain injury [157].

The endocannabinoid system represents a local messenger between the nervous and immune system and is obviously involved in the control of immune activation and neuroprotection. Manipulation of endocannabinoids and/or use of exogenous cannabinoids in vivo can constitute a potent treatment modality against inflammatory disorders. Cannabinoids have been tested in several experimental models of autoimmune disorders such as multiple sclerosis, rheumatoid arthritis, colitis and hepatitis and have been shown to protect the host from the pathogenesis through induction of multiple anti-inflammatory pathways.

Recently, numerous researches have revealed several secrets of the ECS. Although, further information is still needed before ECS is completely comprehended, pharmacological modulation of the ECS seems, nowadays, a viable target which will pave the way for the therapeutic intervention at a wide spectrum of diseases.

\section{References}

1. Lichtman AH (2000) SR 141716 A enhances spatial memory as assessed in a radial-arm maze task in rats. Eur J Pharmacol 404: 175-179. [Crossref]

2. Kunos G, Járai Z, Bátkai S, Goparaju SK, Ishac EJ, et al. (2000) Endocannabinoids as cardiovascular modulators. Chem Phys Lipids 108: 159-168. [Crossref]

3. Di Marzo V, Goparaju SK, Wang L, Liu J, Bátkai S, et al. (2001) Leptin-regulated endocannabinoids are involved in maintaining food intake. Nature 410: 822-825. [Crossref]

4. Pertwee RG (2001) Cannabinoids and the gastrointestinal tract. Gut 48: 859-867. [Crossref]

5. Piomelli D (2003) The molecular logic of endocannabinoid signalling. Nat Rev Neurosci 4: 873-884. [Crossref]

6. Rodríguez de Fonseca F, Del Arco I, Bermudez-Silva FJ, Bilbao A, Cippitelli A, et al. (2005) The endocannabinoid system: physiology and pharmacology. Alcohol Alcohol 40: 2-14. [Crossref]
7. Mackie K (2006) Cannabinoid receptors as therapeutic targets. Annu Rev Pharmacol Toxicol 46: 101-122. [Crossref]

8. Di Marzo V (2008) Endocannabinoids: synthesis and degradation. Rev Physiol Biochem Pharmacol 160: 1-24. [Crossref]

9. Viveros MP, de Fonseca FR, Bermudez-Silva FJ, McPartland JM (2008) Critical role of the endocannabinoid system in the regulation of food intake and energymetabolism, with phylogenetic, developmental, and pathophysiological implications. Endocr Metab Immune Disord Drug Targets 8: 220-230. [Crossref]

10. Kunos G, Osei-Hyiaman D, Bátkai S, Sharkey KA, Makriyannis A (2009) Should peripheral $\mathrm{CB}(1)$ cannabinoid receptors be selectively targeted for therapeutic gain? Trends Pharmacol Sci 30: 1-7. [Crossref]

11. Izzo AA, Sharkey KA (2010) Cannabinoids and the gut: new developments and emerging concepts. Pharmacol Ther 126: 21-38. [Crossref]

12. Zogopoulos P, Vasileiou I, Patsouris E, Theocharis SE (2013) The role of endocannabinoids in pain modulation. Fundam Clin Pharmacol 27: 64-80. [Crossref]

13. Zogopoulos P, Vasileiou I, Patsouris E, Theocharis S (2013) The neuroprotective role of endocannabinoids against chemical-induced injury and other adverse effects. $J$ Appl Toxicol 33: 246-264.

14. Zogopoulos P, Korkolopoulou P, Patsouris E, Theocharis S (2015) The antitumor action of cannabinoids on glioma tumorigenesis. Histol Histopathol 30: 629-645. [Crossref]

15. Devane WA, Hanus L, Breuer A, Pertwee RG, Stevenson LA, et al. (1992) Isolation and structure of a brain constituent that binds to the cannabinoid receptor. Science 258 : 1946-1949. [Crossref]

16. Mechoulam R, Ben-Shabat S, Hanus L, Ligumsky M, Kaminski NE, et al. (1995) Identification of an endogenous 2-monoglyceride, present in canine gut, that binds to cannabinoid receptors. Biochem Pharmacol 50: 83-90. [Crossref]

17. Stella N, Schweitzer P, Piomelli D (1997) A second endogenous cannabinoid that modulates long-term potentiation. Nature 388: 773-778. [Crossref]

18. Pertwee RG, Ross RA (2002) Cannabinoid receptors and their ligands. Prostaglandins Leukot Essent Fatty Acids 66: 101-121. [Crossref]

19. Bisogno T, Martire A, Petrosino S, Popoli P, Di Marzo V (2008) Symptom-related changes of endocannabinoid and palmitoylethanolamide levels in brain areas of R6/2 mice, a transgenic model of Huntington's disease. Neurochem Int 52: 307-313. [Crossref]

20. Bari M, Battista N, Fezza F, Gasperi V, Maccarrone M (2006) New insights into endocannabinoid degradation and its therapeutic potential. Mini Rev Med Chem 6: 257 268. [Crossref]

21. Matsuda LA, Lolait SJ, Brownstein MJ, Young AC, Bonner TI (1990) Structure of a cannabinoid receptor and functional expression of the cloned cDNA. Nature 346: 561-564. [Crossref]

22. Munro S, Thomas KL, Abu-Shaar M (1993) Molecular characterization of a peripheral receptor for cannabinoids. Nature 365: 61-65. [Crossref]

23. Galve-Roperh I, Sanchez C, Cortes ML, Gómez del Pulgar T, Izquierdo M, et al. (2000) Anti-tumoral action of cannabinoids: involvement of sustained ceramide accumulation and extracellular signal-regulated kinase activation. Nat Med 6: 313-319. [Crossref]

24. Guzmán M, Sánchez C, Galve-Roperh I (2001) Control of the cell survival/death decision by cannabinoids. $J$ Mol Med (Berl) 78: 613-625. [Crossref]

25. Marsicano G, Goodenough S, Monory K, Hermann H, Eder M, et al. (2003) CB1 cannabinoid receptors and on-demand defense against excitotoxicity. Science 302: 84 88. [Crossref]

26. Engeli S, Böhnke J, Feldpausch M, Gorzelniak K, Janke J, et al. (2005) Activation of the peripheral endocannabinoid system in human obesity. Diabetes 54: 2838-2843. [Crossref]

27. Rajesh M, Mukhopadhyay P, Bátkai S, Haskó G, Liaudet L, et al. (2007) Cannabidiol attenuates high glucose-induced endothelial cell inflammatory response and barrier disruption. Am J Physiol Heart Circ Physiol 293: H610-619. [Crossref]

28. Rajesh M, Pan H, Mukhopadhyay P, Batkai S, Osei-Hyiaman D, et al. (2007) Cannabinoid-2 receptor agonist HU-308 protects against hepatic ischemia/reperfusion injury by attenuating oxidative stress, inflammatory response, and apoptosis. J Leukoc Biol 82: 1382-1389. [Crossref]

29. Rajesh M, Mukhopadhyay P, Hasko G, Huffman JW, Mackie K, et al. (2008) CB2 cannabinoid receptor agonists attenuate TNF-a-induced human vascular smooth 
muscle cell proliferation and migration. Br J Pharmacol 153: 347-357. [Crossref]

30. Herkenham M (1991) Characterization and localization of cannabinoid receptors in brain: an in vitro technique using slide-mounted tissue sections. NIDA Res Monogr 112: 129-145. [Crossref]

31. Herkenham M, Lynn AB, Johnson MR, Melvin LS, de Costa BR, et al. (1991) Characterization and localization of cannabinoid receptors in rat brain: a quantitative in vitro autoradiographic study. J Neurosci 11: 563-583. [Crossref]

32. Glass M, Brotchie JM, Maneuf YP (1997) Modulation of neurotransmission by cannabinoids in the basal ganglia. Eur J Neurosci 9: 199-203. [Crossref]

33. Glass M, Dragunow M, Faull RL (1997) Cannabinoid receptors in the human brain: a detailed anatomical and quantitative autoradiographic study in the fetal, neonatal and adult human brain. Neuroscience 77: 299-318. [Crossref]

34. Farquhar-Smith WP, Egertová M, Bradbury EJ, McMahon SB, Rice AS, et al. (2000) Cannabinoid $\mathrm{CB}(1)$ receptor expression in rat spinal cord. Mol Cell Neurosci 15: 510521. [Crossref]

35. Iversen L (2003) Cannabis and the brain. Brain 126: 1252-1270. [Crossref]

36. Engler B, Freiman I, Urbanski M, Szabo B (2006) Effects of exogenous and endogenous cannabinoids on GABAergic neurotransmission between the caudate-putamen and the globus pallidus in the mouse. J Pharmacol Exp Ther 316: 608-617. [Crossref]

37. Kofalvi A, Rodrigues RJ, Ledent C, Mackie K, Vizi ES, et al. (2005) Involvement of cannabinoid receptors in the regulation of neurotransmitter release in the rodent striatum: A combined immunochemical and pharmacological analysis. J Neurosci 25 : 2874-2884. [Crossref]

38. Kawamura Y, Fukaya M, Maejima T, Yoshida T, Miura E, et al. (2006) The CB1 cannabinoid receptor is the major cannabinoid receptor at excitatory presynaptic sites in the hippocampus and cerebellum. J Neurosci 26: 2991-3001. [Crossref]

39. Mátyás F, Yanovsky Y, Mackie K, Kelsch W, Misgeld U, et al. (2006) Subcellular localization of type 1 cannabinoid receptors in the rat basal ganglia. Neuroscience 137 337-361. [Crossref]

40. Carrier EJ, Kearn CS, Barkmeier AJ, Breese NM, Yang W, et al. (2004) Cultured rat microglial cells synthesize the endocannabinoid 2-arachidonylglycerol, which increases proliferation via a CB2 receptor-dependent mechanism. Mol Pharmacol 65: 999-1007. [Crossref]

41. Gong JP, Onaivi ES, Ishiguro H, Liu QR, Tagliaferro PA, et al. (2006) Cannabinoid $\mathrm{CB} 2$ receptors: immunohistochemical localization in rat brain. Brain Res 1071: 10-23. [Crossref]

42. Sheng WS, Hu S, Min X, Cabral GA, Lokensgard JR, et al. (2005) Synthetic cannabinoid WIN55, 212-2 inhibits generation of inflammatory mediators by IL-1betastimulated human astrocytes. Glia 49: 211-219. [Crossref]

43. Onaivi ES, Ishiguro H, Gong JP, Patel S, Perchuk A, et al. (2006) Discovery of the presence and functional expression of cannabinoid CB2 receptors in brain. Ann NY Acad Sci 1074: 514-536. [Crossref]

44. Cabral GA, Raborn ES, Griffin L, Dennis J, Marciano-Cabral F (2008) CB2 receptors in the brain: role in central immune function. Br J Pharmacol 153: 240-251. [Crossref]

45. Cabral GA, Griffin-Thomas L (2008) Cannabinoids as therapeutic agents for ablating neuroinflammatory disease. Endocr Metab Immune Disord Drug Targets 8: 159-172. [Crossref]

46. Sagredo O, González S, Aroyo I, Pazos MR, Benito C, et al. (2009) Cannabinoid $\mathrm{CB} 2$ receptor agonists protect the striatum against malonate toxicity: relevance for Huntington's disease. Glia 57: 1154-1167. [Crossref]

47. Golech SA, McCarron RM, Chen Y, Bembry J, Lenz F, et al. (2004) Human brain endothelium: coexpression and function of vanilloid and endocannabinoid receptors. Brain Res Mol Brain Res 132: 87-92. [Crossref]

48. Van Sickle MD, Duncan M, Kingsley PJ, Mouihate A, Urbani P, et al. (2005) Identification and functional characterization of brainstem cannabinoid CB2 receptors. Science 310: 329-332. [Crossref]

49. Wotherspoon G, Fox A, McIntyre P, Colley S, Bevan S, et al. (2005) Peripheral nerve injury induces cannabinoid receptor 2 protein expression in rat sensory neurons. Neuroscience 135: 235-245. [Crossref]

50. Ashton JC, Friberg D, Darlington CL, Smith PF (2006) Expression of the cannabinoid CB2 receptor in the rat cerebellum: an immunohistochemical study. Neurosci Lett 396: 113-116. [Crossref]

51. Galiègue S, Mary S, Marchand J, Dussossoy D, Carrière D, et al. (1995) Expression of central and peripheral cannabinoid receptors in human immune tissues and leukocyte subpopulations. Eur J Biochem 232: 54-61. [Crossref]

52. Schatz AR, Lee M, Condie RB, Pulaski JT, Kaminski NE (1997) Cannabinoid receptor CB1 and CB2: a characterization of expression and adenylate cyclase modulation within the immune system. Toxicol Appl Pharmacol 142: 278-287. [Crossref]

53. Gaoni Y, Mechoulam R (1971) The isolation and structure of delta-1tetrahydrocannabinol and other neutral cannabinoids from hashish. J Am Chem Soc 93: 217-224. [Crossref]

54. Felder CC, Joyce KE, Briley EM, Glass M, Mackie KP, et al. (1998) LY320135, a novel cannabinoid $\mathrm{CB} 1$ receptor antagonist, unmasks coupling of the CB1 receptor to stimulation of cAMP accumulation. J Pharmacol Exp Ther 284: 291-297. [Crossref]

55. McAllister SD, Glass $\mathrm{M}(2002) \mathrm{CB}(1)$ and $\mathrm{CB}(2)$ receptor-mediated signalling: a focus on endocannabinoids. Prostaglandins Leukot Essent Fatty Acids 66: 161-171. [Crossref]

56. Sugiura T, Kondo S, Sukagawa A, Nakane S, Shinoda A, et al. (1995) 2-Arachidonoylglycerol: a possible endogenous cannabinoid receptor ligand in brain. Biochem Biophys Res Commun 215: 89-97. [Crossref]

57. Hanus L, Abu-Lafi S, Fride E, Breuer A, Vogel Z, et al. (2001) 2-arachidonyl glyceryl ether, an endogenous agonist of the cannabinoid CB1 receptor. Proc Natl Acad Sci U $S$ A 98: 3662-3665. [Crossref]

58. Huang SM, Bisogno T, Trevisani M, Al-Hayani A, De Petrocellis L, et al. (2002) An endogenous capsaicin-like substance with high potency at recombinant and native vanilloid VR1 receptors. Proc Natl Acad Sci U S A 99: 8400-8405. [Crossref]

59. Porter AC, Sauer JM, Knierman MD, Becker GW, Berna MJ, et al. (2002) Characterization of a novel endocannabinoid, virodhamine, with antagonist activity at the CB1 receptor. J Pharmacol Exp Ther 301: 1020-1024. [Crossref]

60. Nagarkatti P, Pandey R, Rieder SA, Hegde VL, Nagarkatti M (2009) Cannabinoids as novel anti-inflammatory drugs. Future Med Chem 1: 1333-1349. [Crossref]

61. Freund TF, Katona I, Piomelli D (2003) Role of endogenous cannabinoids in synaptic signaling. Physiol Rev 83: 1017-1066. [Crossref]

62. Nagayama T, Sinor AD, Simon RP, Chen J, Graham SH, et al. (1999) Cannabinoids and neuroprotection in global and focal cerebral ischemia and in neuronal cultures. $J$ Neurosci 19: 2987-2995. [Crossref]

63. Panikashvili D, Simeonidou C, Ben-Shabat S, Hanus L, Breuer A, et al. (2001) An endogenous cannabinoid (2-AG) is neuroprotective after brain injury. Nature 413: 527 531. [Crossref]

64. Parmentier-Batteur S, Jin K, Mao XO, Xie L, Greenberg DA (2002) Increased severity of stroke in CB1 cannabinoid receptor knock-out mice. J Neurosci 22: 9771-9775. [Crossref]

65. Wallace MJ, Blair RE, Falenski KW, Martin BR, DeLorenzo RJ (2003) The endogenous cannabinoid system regulates seizure frequency and duration in a model of temporal lobe epilepsy. J Pharmacol Exp Ther 307: 129-137. [Crossref]

66. Klegeris A, Bissonnette CJ, McGeer PL (2003) Reduction of human monocytic cell neurotoxicity and cytokine secretion by ligands of the cannabinoid-type $\mathrm{CB} 2$ receptor Br J Pharmacol 139: 775-786. [Crossref]

67. Stella N (2004) Cannabinoid signaling in glial cells. Glia 48: 267-277. [Crossref]

68. Baker D, Pryce G, Croxford JL, Brown P, Pertwee RG, et al. (2001) Endocannabinoids control spasticity in a multiple sclerosis model. FASEB J 15: 300-302. [Crossref]

69. Chang YH, Lee ST, Lin WW (2001) Effects of cannabinoids on LPS-stimulated inflammatory mediator release from macrophages: involvement of eicosanoids. $J \mathrm{Cell}$ Biochem 81: 715-723. [Crossref]

70. Walter L, Stella N (2003) Endothelin-1 increases 2-arachidonoyl glycerol (2-AG) production in astrocytes. Glia $44: 85-90$. [Crossref]

71. Walter L, Franklin A, Witting A, Wade C, Xie Y, et al. (2003) Nonpsychotropic cannabinoid receptors regulate microglial cell migration. J Neurosci 23: 1398-1405. [Crossref]

72. Rom S, Persidsky Y (2013) Cannabinoid receptor 2: potential role in immunomodulation and neuroinflammation. J Neuroimmune Pharmacol 8: 608-620. [Crossref]

73. Hillard CJ (2000) Endocannabinoids and vascular function. J Pharmacol Exp Ther 294: 27-32. [Crossref]

74. van der Stelt M, Veldhuis WB, van Haaften GW, Fezza F, Bisogno T, et al. (2001) Exogenous anandamide protects rat brain against acute neuronal injury in vivo. $J$ 


\section{Neurosci 21: 8765-8771. [Crossref]}

75. Marsicano G, Moosmann B, Hermann H, Lutz B, Behl C (2002) Neuroprotective properties of cannabinoids against oxidative stress: role of the cannabinoid receptor CB1. J Neurochem 80: 448-456. [Crossref]

76. Walter L, Stella N (2004) Cannabinoids and neuroinflammation. Br J Pharmacol 141: 775-785. [Crossref]

77. Di Marzo V, Matias I (2005) Endocannabinoid control of food intake and energy balance. Nat Neurosci 8: 585-589. [Crossref]

78. Eljaschewitsch E, Witting A, Mawrin C, Lee T, Schmidt PM, et al. (2006) The endocannabinoid anandamide protects neurons during CNS inflammation by induction of MKP-1 in microglial cells. Neuron 49: 67-79. [Crossref]

79. McGeer PL, Itagaki S, Boyes BE, McGeer EG (1988) Reactive microglia are positive for HLA-DR in the substantia nigra of Parkinson's and Alzheimer's disease brains. Neurology 38: 1285-1291. [Crossref]

80. Sherman MP, Griscavage JM, Ignarro LJ (1992) Nitric oxide-mediated neuronal injury in multiple sclerosis. Med Hypotheses 39: 143-146. [Crossref]

81. Dickson DW, Lee SC, Mattiace LA, Yen SH, Brosnan C (1993) Microglia and cytokines in neurological disease, with special reference to AIDS and Alzheimer's disease. Glia 7: 75-83. [Crossref]

82. Andersen JK (2004) Oxidative stress in neurodegeneration: cause or consequence? Nat Med 10: S18-25. [Crossref]

83. Craft JM, Watterson DM, Van Eldik LJ (2005) Neuroinflammation: a potential therapeutic target. Expert Opin Ther Targets 9: 887-900. [Crossref]

84. Minghetti L (2005) Role of inflammation in neurodegenerative diseases. Curr Opin Neurol 18: 315-321. [Crossref]

85. Hoozemans JJ, Veerhuis R, Rozemuller JM, Eikelenboom P (2006) Neuroinflammation and regeneration in the early stages of Alzheimer's disease pathology. Int $J$ Dev Neurosci 24: 157-165. [Crossref]

86. Liu B, Hong JS (2003) Role of microglia in inflammation-mediated neurodegenerative diseases: mechanisms and strategies for therapeutic intervention. J Pharmacol Exp Ther 304: 1-7. [Crossref]

87. Navarrete CM, Fiebich BL, de Vinuesa AG, Hess S, de Oliveira AC, et al. (2009) Opposite effects of anandamide and $\mathrm{N}$-arachidonoyl dopamine in the regulation of prostaglandin E and 8-iso-PGF formation in primary glial cells. J Neurochem 109: 452-464. [Crossref]

88. Sinor AD, Irvin SM, Greenberg DA (2000) Endocannabinoids protect cerebral cortical neurons from in vitro ischemia in rats. Neurosci Lett 278: 157-160. [Crossref]

89. Cernak I, Vink R, Natale J, Stoica B, Lea PM 4th, et al. (2004) The "dark side" of endocannabinoids: a neurotoxic role for anandamide. J Cereb Blood Flow Metab 24: 564-578. [Crossref]

90. Movsesyan VA, Stoica BA, Yakovlev AG, Knoblach SM, Lea PM 4th, et al. (2004) Anandamide-induced cell death in primary neuronal cultures: role of calpain and caspase pathways. Cell Death Differ 11: 1121-1132. [Crossref]

91. Akundi RS, Candelario-Jalil E, Hess S, Hüll M, Lieb K, et al. (2005) Signal transduction pathways regulating cyclooxygenase-2 in lipopolysaccharide-activated primary rat microglia. Glia 51: 199-208. [Crossref]

92. Pepicelli O, Fedele E, Berardi M, Raiteri M, Levi G, et al. (2005) Cyclo-oxygenase-1 and -2 differently contribute to prostaglandin E2 synthesis and lipid peroxidation after in vivo activation of N-methyl-Daspartate receptors in rat hippocampus. $J$ Neurochem 93: 1561- 1567. [Crossref]

93. Candelario-Jalil E, Akundi RS, Bhatia HS, Lieb K, Appel K, et al. (2006) Ascorbic acid enhances the inhibitory effect of aspirin on neuronal cyclooxygenase-2-mediated prostaglandin E2 production. J Neuroimmunol 174: 39-51. [Crossref]

94. McKallip RJ, Lombard C, Martin BR, Nagarkatti M, Nagarkatti PS (2002) Delta(9)tetrahydrocannabinol-induced apoptosis in the thymus and spleen as a mechanism of immunosuppression in vitro and in vivo. J Pharmacol Exp Ther 302: 451-465. [Crossref]

95. Ziring D, Wei B, Velazquez P, Schrage M, Buckley NE, et al. (2006) Formation of B and $\mathrm{T}$ cell subsets require the cannabinoid receptor CB2. Immunogenetics 58: 714-725. [Crossref]

96. Chuchawankul S, Shima M, Buckley NE, Hartmann CB, McCoy KL (2004) Role of cannabinoid receptors in inhibiting macrophage costimulatory activity. Int
Immunopharmacol 4: 265-278. [Crossref]

97. Nilsson O, Fowler CJ, Jacobsson SO (2006) The cannabinoid agonist WIN 55,2122 inhibits TNF-alpha-induced neutrophil transmigration across ECV304 cells. Eur $J$ Pharmacol 547: 165-173. [Crossref]

98. Mechoulam R, Panikashvili D, Shohami E (2002) Cannabinoids and brain injury: therapeutic implications. Trends $\mathrm{Mol} \mathrm{Med} \mathrm{8:} \mathrm{58-61.} \mathrm{[Crossref]}$

99. van der Stelt M, Veldhuis WB, Maccarrone M, Bär PR, Nicolay K, et al. (2002) Acute neuronal injury, excitotoxicity, and the endocannabinoid system. Mol Neurobiol 26 : 317-346. [Crossref]

100. Melis M, Pillolla G, Bisogno T, Minassi A, Petrosino S, et al. (2006) Protective activation of the endocannabinoid system during ischemia in dopamine neurons. Neurobiol Dis 24: 15-27. [Crossref]

101. Facchinetti F1, Del Giudice E, Furegato S, Passarotto M, Leon A (2003) Cannabinoids ablate release of TNFalpha in rat microglial cells stimulated with lypopolysaccharide. Glia 41: 161-168. [Crossref]

102. Comelli F, Giagnoni G, Bettoni I, Colleoni M, Costa B (2007) The inhibition of monoacylglycerol lipase by URB602 showed an anti-inflammatory and antinociceptive effect in a murine model of acute inflammation. Br J Pharmacol 152 787-794. [Crossref]

103. Zhang J, Chen C (2008) Endocannabinoid 2-arachidonoylglycerol protects neurons by limiting COX-2 elevation. J Biol Chem 283: 22601-22611. [Crossref]

104. Kishimoto S, Oka S, Gokoh M, Sugiura T (2006) Chemotaxis of human peripheral blood eosinophils to 2-arachidonoylglycerol: comparison with other eosinophil chemoattractants. Int Arch Allergy Immunol 140 Suppl 1: 3-7. [Crossref]

105. Oka S, Ikeda S, Kishimoto S, Gokoh M, Yanagimoto S, et al. (2004) 2-arachidonoylglycerol, an endogenous cannabinoid receptor ligand, induces the migration of EoL-1 human eosinophilic leukemia cells and human peripheral blood eosinophils. J Leukoc Biol 76: 1002-1009. [Crossref]

106. Oka S, Wakui J, Ikeda S, Yanagimoto S, Kishimoto S, et al. (2006) Involvement of the cannabinoid CB2 receptor and its endogenous ligand 2-arachidonoylglycerol in oxazolone-induced contact dermatitis in mice. J Immunol 177: 8796-8805. [Crossref]

107. Kozak KR, Prusakiewicz JJ, Marnett LJ (2004) Oxidative metabolism of endocannabinoids by COX-2. Curr Pharm Des 10: 659-667. [Crossref]

108. Sang N, Chen C (2006) Lipid signaling and synaptic plasticity. Neuroscientist 12: 425-434. [Crossref]

109. Sang N, Zhang J, Chen C (2007) COX-2 oxidative metabolite of endocannabinoid 2-AG enhances excitatory glutamatergic synaptic transmission and induces neurotoxicity. J Neurochem 102: 1966-1977. [Crossref]

110. Hurley SD, Olschowka JA, O’Banion MK (2002) Cyclooxygenase inhibition as a strategy to ameliorate brain injury. J Neurotrauma 19: 1-15. [Crossref]

111. Manabe Y, Anrather J, Kawano T, Niwa K, Zhou P, et al. (2004) Prostanoids, not reactive oxygen species, mediate COX-2-dependent neurotoxicity. Ann Neurol 55: 668-675. [Crossref]

112. Chen C, Bazan NG (2005) Endogenous PGE2 regulates membrane excitability and synaptic transmission in hippocampal CA1 pyramidal neurons. $J$ Neurophysiol 93: 929-941. [Crossref]

113. Liang X, Wu L, Hand T, Andreasson K (2005) Prostaglandin D2 mediates neuronal protection via the DP1 receptor. J Neurochem 92: 477-486. [Crossref]

114. Sang N, Zhang J, Marcheselli V, Bazan NG, Chen C. (2005) Postsynaptically synthesized prostaglandin E2 (PGE2) modulates hippocampal synaptic transmission via a presynaptic PGE2 EP2 receptor. J Neurosci 25: 9858-9870. [Crossref]

115. Kawano T1, Anrather J, Zhou P, Park L, Wang G, et al. (2006) Prostaglandin E2 EP1 receptors: downstream effectors of COX-2 neurotoxicity. Nat Med 12: 225-229. [Crossref]

116. Akaike A, Kaneko S, Tamura Y, Nakata N, Shimoi H, et al. (1994) Prostaglandin E2 protects cultured cortical neurons against N-methyl-D-aspartate receptor-mediated glutamate cytotoxicity. Brain Res 663: 237-244. [Crossref]

117. Kim EJ, Kwon KJ, Park JY, Lee SH, Moon CH, et al. (2002) Neuroprotective effects of prostaglandin E2 or cAMP against microglial and neuronal free radical mediated toxicity associated with inflammation. $J$ Neurosci Res 70: 97-107. [Crossref]

118. Lee EO, Shin YJ, Chong YH. (2004) Mechanisms involved in prostaglandin E2 mediated neuroprotection against TNF-a: possible involvement of multiple signal 
transduction and b-catenin/T-cell factor. J Neuroimmunol 155: 21-31. [Crossref]

119. McCullough L, Wu L, Haughey N, Liang X, Hand T, et al. (2004) Neuroprotective function of the PGE2 EP2 receptor in cerebral ischemia. $J$ Neurosci 24: 257-268. [Crossref]

120. Nakayama M, Uchimura K, Zhu RL, Nagayama T, Rose ME, et al. (1998) Cyclooxygenase-2 inhibition prevents delayed death of CA1 hippocampal neurons following global ischemia. Proc Natl Acad Sci U S A 95: 10954-10959. [Crossref]

121. Ho L, Pieroni C, Winger D, Purohit DP, Aisen PS, et al. (1999) Regional distribution of cyclooxygenase-2 in the hippocampal formation in Alzheimer's disease. $J$ Neurosci Res 57: 295-303. [Crossref]

122. Mackie K, Stella N (2006) Cannabinoid receptors and endocannabinoids: evidence for new players. AAPS J 8: E298-306. [Crossref]

123. Wagner JA, Varga K, Járai Z, Kunos G (1999) Mesenteric vasodilation mediated by endothelial anandamide receptors. Hypertension 33: 429-434. [Crossref]

124. Franklin A, Parmentier-Batteur S, Walter L, Greenberg DA, Stella N (2003) Palmitoylethanolamide increases after focal cerebral ischemia and potentiates microglial cell motility. J Neurosci 23: 7767-7775. [Crossref]

125. Puffenbarger RA, Boothe AC, Cabral GA (2000) Cannabinoids inhibit LPS-inducible cytokine mRNA expression in rat microglial cells. Glia 29: 58-69. [Crossref]

126. Molina-Holgado F, Lledó A, Guaza C (1997) Anandamide suppresses nitric oxide and TNF-alpha responses to Theiler's virus or endotoxin in astrocytes. Neuroreport 8: 1929-1933. [Crossref]

127. McCarron RM, Shohami E, Panikashvili D, Chen Y, Golech S, et al. (2003) Antioxidant properties of the vasoactive endocannabinoid, 2-arachidonoyl glycerol (2-AG). Acta Neurochir Suppl 86: 271-275. [Crossref]

128. Kluger B, Triolo P, Jones W, Jankovic J (2015) The therapeutic potential of cannabinoids for movement disorders. Mov Disord 30: 313-327. [Crossref]

129. Zimmer A, Zimmer AM, Hohmann AG, Herkenham M, Bonner TI (1999) Increased mortality, hypoactivity, and hypoalgesia in cannabinoid CB1 receptor knockout mice. Proc Natl Acad Sci U S A 96: 5780-5785. [Crossref]

130. Lastres-Becker I, Fezza F, Cebeira M, Bisogno T, Ramos JA, et al. (2001) Changes in endocannabinoid transmission in the basal ganglia in a rat model of Huntington's disease. Neuroreport 12: 2125-2129. [Crossref]

131. Frankel JP, Hughes A, Lees AJ, Stern GM (1990) Marijuana for parkinsonian tremor J Neurol Neurosurg Psychiatry 53: 436. [Crossref]

132. Westlake TM, Howlett AC, Bonner TI, Matsuda LA, Herkenham M (1994) Cannabinoid receptor binding and messenger RNA expression in human brain: an in vitro receptor autoradiography and in situ hybridization histochemistry study of normal aged and Alzheimer's brains. Neurosci 63: 637-652. [Crossref]

133. Velayudhan L, Van Diepen E, Marudkar M, Hands O, Suribhatla S, et al. (2014) Therapeutic potential of cannabinoids in neurodegenerative disorders: a selective review. Curr Pharm Des 20: 2218-2230. [Crossref]

134. Müller-Vahl KR, Kolbe H, Schneider U, Emrich HM (1999) Cannabis in movement disorders. Forsch Komplementarmed 6: 23-27. [Crossref]

135. Glass M, Faull RL, Dragunow M (1993) Loss of cannabinoid receptors in the substantia nigra in Huntington's disease. Neuroscience 56: 523-527. [Crossref]

136. Glass M, Dragunow M, Faull RL (2000) The pattern of neurodegeneration in Huntington's disease: A comparative study of cannabinoid, dopamine, adenosine and GABA(A) receptor alterations in the human basal ganglia in Huntington's disease. Neuroscience 97: 505-519. [Crossref]

137. Bari M, Battista N, Valenza M, Mastrangelo N, Malaponti M, et al. (2013) In vitro and in vivo models of Huntington's disease show alterations in the endocannabinoid system. FEBS J 280: 3376-3388. [Crossref]
138. Pryce G, Ahmed Z, Hankey DJ, Jackson SJ, Croxford JL, et al. (2003) Cannabinoids inhibit neurodegeneration in models of multiple sclerosis. Brain 126: 2191-2202. [Crossref]

139. Baker D, Pryce G, Croxford JL, Brown P, Pertwee RG, et al. (2000) Cannabinoids control spasticity and tremor in a multiple sclerosis model. Nature 404: 84-87. [Crossref]

140. Baker D, Pryce G, Croxford JL, Brown P, Pertwee RG, et al. (2001) Endocannabinoids control spasticity in a multiple sclerosis model. FASEB J 15: 300-302. [Crossref]

141. Di Iorio G, Lupi M, Sarchione F, Matarazzo I, Santacroce R, et al. (2013) The endocannabinoid system: a putative role in neurodegenerative diseases. Int J High Risk Behav Addict 2: 100-106. [Crossref]

142. Pryce G, Cabranes A, Fernández-Ruiz J, Bisogno T, Di Marzo V, et al. (2013) Control of experimental spasticity by targeting the degradation of endocannabinoids using selective fatty acid amide hydrolase inhibitors. Mult Scler 19: 1896-1904. [Crossref]

143. Ferguson B, Matyszak MK, Esiri MM, Perry VH (1997) Axonal damage in acute multiple sclerosis lesions. Brain 120: 393-399. [Crossref]

144. Killestein J, Uitdehaag BM, Polman CH (2004) Cannabinoids in multiple sclerosis: do they have a therapeutic role? Drugs 64: 1-11. [Crossref]

145. Koprowski H, Zheng YM, Heber-Katz E, Fraser N, Rorke L, et al. (1993) In vivo expression of inducible nitric oxide synthase in experimentally induced neurologic diseases. Proc Natl Acad Sci U S A 90: 3024-3027. [Crossref]

146. Malfitano AM, Matarese G, Bifulco M (2005) From cannabis to endocannabinoids in multiple sclerosis: a paradigm of central nervous system autoimmune diseases. Cur Drug Targets CNS Neurol Disord 4: 667-675. [Crossref]

147. Chiurchiù V, Cencioni MT, Bisicchia E, De Bardi M, Gasperini C, et al. (2013) Distinct modulation of human myeloid and plasmacytoid dendritic cells by anandamide in multiple sclerosis. Ann Neurol 73: 626-636. [Crossref]

148. Al-Chalabi A1, Leigh PN (2000) Recent advances in amyotrophic lateral sclerosis Curr Opin Neurol 13: 397-405. [Crossref]

149. Fezza F, Marrone MC, Avvisati R, Di Tommaso M, Lanuti M, et al. (2014) Distinct modulation of the endocannabinoid system upon kainic acid-induced in vivo seizures and in vitro epileptiform bursting. Mol Cell Neurosci 62: 1-9. [Crossref]

150. Monory K, Massa F, Egertová M, Eder M, Blaudzun H, et al. (2006) The endocannabinoid system controls key epileptogenic circuits in the hippocampus. Neuron 51: 455-466. [Crossref]

151. Alger BE (2014) Seizing an opportunity for the endocannabinoid system. Epilepsy Curr 14: 272-276. [Crossref]

152. Centonze D, Bari M, Rossi S, Prosperetti C, Furlan R, et al. (2007) The endocannabinoid system is dysregulated in multiple sclerosis and in experimental autoimmune encephalomyelitis. Brain 130: 2543-2553. [Crossref]

153. Centonze D, Finazzi-Agrò A, Bernardi G, Maccarrone M (2007) The endocannabinoid system in targeting inflammatory neurodegenerative diseases. Trends Pharmacol Sci 28: 180-187. [Crossref]

154. Galve-Roperh I, Aguado T, Palazuelos J, Guzmán M (2008) Mechanisms of control of neuron survival by the endocannabinoid system. Curr Pharm Des 14: 2279-2288. [Crossref]

155. Pacher P, Bátkai S, Kunos G (2006) The endocannabinoid system as an emerging target of pharmacotherapy. Pharmacol Rev 58: 389-462. [Crossref]

156. Maccarrone M (2008) Endocannabinoid signaling and neuroinflammatory diseases. Curr Pharm Des 14: 2252-2253. [Crossref]

157. Mechoulam R, Shohami E (2007) Endocannabinoids and traumatic brain injury. Mol Neurobiol 36: 68-74. [Crossref]

Copyright: (C2015 Zogopoulos P. This is an open-access article distributed under the terms of the Creative Commons Attribution License, which permits unrestricted use, distribution, and reproduction in any medium, provided the original author and source are credited. 